\title{
Customer Relationship Management in Business-to- Business Marketing: The Impact on Corporate Performance
}

\author{
Moh. Hasymi Quzwen ${ }^{1, *}$ Ratih Hurriyati ${ }^{2}$ Mokh. Adib Sultan ${ }^{3}$ \\ ${ }^{1}$ Universitas Pendidikan Indonesia \\ ${ }^{2}$ Universitas Pendidikan Indonesia \\ ${ }^{3}$ Universitas Pendidikan Indonesia \\ *Corresponding author.Email: quzwen@gmail.com
}

\begin{abstract}
The main purpose of this study is to examine the theoretical and empirical evidence on the causal relationship between the implementation of customer relationship management (CRM) and corporate performance. A research conceptual model was developed to depict the impact of three - organizational, strategic, cultural - factors on CRM implementation and its implications on corporate performance. The analyses was made up of 120 questionnaires from courier companies all over Indonesia. Since in courier industry, customers' need and preferences change frequently, as do the competitors, so the moderating effect of market turbulence (market dynamism and market uncertainty) on the relationship between CRM implementation and corporate performance was also investigated. A structural equation modelling (SEM) test with maximum likelihood estimation was performed to test the relationship among organizational-strategic-cultura factors, CRM implementation, and corporate performance. The results showed that organizational, strategic, and cultural factors had positive effects on CRM implementation. The results also revealed that CRM implementations had significant positive effects on corporate performances of courier companies that performed business-to-business marketing. Additionally, it was found that market turbulence negatively moderated the relationship between CRM implementation and corporate performance.
\end{abstract}

Keywords: Customer Relationship Management, Business To Business Marketing, Corporate Performance, Market Turbulence, Courier Industry.

\section{INTRODUCTION}

The implementation of customer relationship management (CRM) has been widely accepted as important aspect for increasing corporate performance. However, some research found different specific findings. Reference [1] found that CRM implementations failed to meet fundamental business goals and even damaged existing customer relationships [2] CRM implementations also had a high probability of failure [35]. Several studies showed that there were positive relationships between a company's CRM implementation and its practice of organizational, strategic, and cultural issues. Three organizational issues - organizational integration, executive commitment, system readiness; and three strategic issues - vision, planning, customer-centred culture; and two cultural issues - networking, human interaction, had an impact on a company's CRM implementation [6].

Meanwhile, CRM is a multi-dimensional construct consisting of three broad behavioral elements: key customer focus, knowledge management, and relationship marketing [7-9]. The other important findings from previous research is that CRM implementations had a significant positive effect on organizational performance [10]. This study demonstrates how CRM systems are implemented by courier companies that perform business-to-business marketing in Indonesia and how they affect corporate performances.

\subsection{Business-to-Business (B2B) Marketing}

Business-to-business (B2B) marketing is the marketing of goods and services to commercial 
enterprises, governments, and other non-profit organizations for use in goods and services they produce to sell to other industrial customers [11]. B2B marketing is also called commercial marketing or industrial marketing [12]. In the post-industrial era, the parties communicate with other buyers or sellers in order to better understand the character of the potential business partner. As both partners are more committed, they are more eager in terms of their relationship in taking greater risk, such as sharing more confidential information in order to be successful [13].

\subsection{Customer Relationship Management (CRM)}

Customer relationship management (CRM) is defined as a management philosophy arising in close connection with the union of marketing and information technology [14]. Reference [15] provided a technical definition of CRM by describing it as a method that significantly uses information technology like databases and the internet to make effective use of the process of relationship marketing. The implementation of CRM is one of the core organizational processes that focuses on establishing, maintaining, and enhancing long term associations with customers as advocated by relationship marketing [16]. CRM solutions enable organizations to achieve positive effects, such as increased sales, profits, greater competitive advantage in the market, increasing costumer loyality and customer satisfaction, generate new knowledge about customers, improve the performance and the quality of customer relationships, acquire new customers, encourage existing customers to purchase, maintain good relation with customers as well as increase value for customers, and thus the image of an organization can be improved [17]. CRM can also support the organization in strengthening customer relationships, customer saticfaction, efficiency of internal processes, and achieving higher incomes [18]. CRM implementation is made up of three constructs which are key customer focus, knowledge management, and relationship marketing [19] First indicator, key customer focus is when the employees focus on delivering the outstanding services to regulars [20]. Secondly, core competences are found due to the abilities and experience of the people who do the work, and may not be present in person [21]. They need to be shared inside organization so they turn into the cumulative. CRM can be defined as knowledge management approach related to customers with the purpose of exploring and using customer knowledge to build lasting personal relationships with customers [22]. The third indicator of CRM implementation is relationship marketing performed to establish, maintain, and enhance relationships with customers and other partners, at a profit, so that the objectives of the parties involved are met [23]. The success of CRM implementation is influenced by three corporate components which are organizational, strategic, and cultural factors.

\subsection{Organizational factors}

CRM is not just a marketing projects but an organizational-wide project. Research indicated that organizational factors were closely related to a company's performance in CRM [6] The implementation of CRM strategy requires the approval and commitment of senior management, effective communication between the different departements of the company, and mandatory training programs on customer loyalty for all employees [24]. CRM is a complex concept requiring appropriate business process and integrated systems. In addition, the study demonstrated the relevance of the need for effective leadership, sourcing, communication and evaluation within CRM strategies [25]. For a better implementation of CRM solutions, it was demonstrated that the establishment of CRM in banks could not be effective without taking several organizational factors into account [26]. Moreover, CRM technology is characterized as costly and complex innovation that needs integrated information systems, costly infrastructure facilitation, and advanced technologycal knowledge and skills for its usage and implementation [27]. CRM technology also helped improve organizational performance by using networking technologies to expand CRM applications to major suppliers and customers [28]. Thus, organizational factors such as degree of integration [29], executive commitment [30], and system readiness [31] can have positive impact on CRM implementation.

\subsection{Strategic factors}

CRM is a business strategy based on a customer focus philosophy. Reference [32] viewed CRM as a strategy that can help commercial banks to build long-lasting relationships with their customers and increase their profits through the right management system and the application of customer-focused strategies. Reference [33] also described CRM as an enterprise-wide business strategy designed to optimize revenue and customer satisfaction by organizing the organization around customer segments. Reference [34] defined CRM as the core business strategy that integrates internal process and functions, and external networks, to create and deliver value to targeted customers, at a profit. A clear strategy ensures the focus of CRM implementation [35]. As a business strategy, CRM implementation is affected by strategic issues such as clear vision [6], project management [35], and project budgeting plan [36]. Furthermore, it is critical for the corporate to have a customer-centred culture while implementing CRM [37]. 


\subsection{Cultural factors}

CRM is about building long term relationship with profitable customers, so that culture has significant impact on the relationship building process. Creating an organizational culture that encourages organizational adaptive learning will help in creating the change needed to gain the benefits intended from the implementation of CRM projects [38]. Recently, there has been an increase in reported CRM failures which indicate that the implementations are not just technical issues, but encompass wider behavior and cultural factors. Reference [39] found that cuture was of high importance for the design and use of CRM systems. This importance of culture is relevant in the fact that the successful use of CRM systems depends in large parts on the underlying individual, organizational and societal cultures. Organizations with an appropriate organizational culture are more likely to enjoy financially desirable CRM outcomes [40]. CRM implementation will not succeed unless a proper cultural foundation exists. In relationship management, networking is also considered as an important method for relationship building especially in buyer and seller relationships [41]. Networking can be considered as drawing on connections or networks in order to secure business favours. Human interaction is also a critical aspect of the relationship building process [42]. Another finding showed that human interaction, organizational integration components, and vision were important in the implementation of CRM [6]. Following the review above, it is hypothesized that:

H1. Organizational, strategic, and cultural factors have significant positive effects on CRM implementation.

\subsection{Corporate Performance}

Corporate performance refers to how well a corporate achieves its market orientation and financial goals [43]. Some studies showed that there was a significant effect between CRM implementation and corporate performance. It was found that relationship marketing had a positive influence on the four aspects of organizational performance in services namely financial, customer, internal process, and learning and growth [9]. In financial institutions, [44] found a positive relationship of CRM on marketing performance. In SMEs of food and manufacturing industry, CRM practices are the important element in increasing organizational performance [10]. Another study found that CRM had a significant effect on the SMEs performance [45]. In banking sector, the role of customer relationship management had a positive or a very good sign to explain the level of organizational performance [46]. There was also a significant effect of CRM dimensions on bank performance [47]. In tourism sector, [48] study demonstrated a significant relationship between CRM dimensions and hotel performance. The study which was conducted in three countries - Austria,
Germany and Switzerland in Fall 2001 by [49] found that implementing CRM processes had a moderate positive association with both perceptual and objective company performance. On the other hand, CRM did not affect firm performance directly. Rather, the CRM-performance link was fully mediated by differentiation and cost leadership [50]. Corporate performance is made up of four constructs which are finance, customer, internal process, and learning and growth. To examine the impact of CRM implementation on corporate performance, hypotheses were constructed as follow:

H2. CRM implementation has significant positive effect on corporate performance.

\subsection{Market Turbulence}

As a moderating variable, market turbulence moderated the relationship between CRM implementation and corporate performance. Market turbulence reflects rapid changing buyer preferences, wide-ranging needs and wants, ongoing buyer entry and exit from the market place, and constant emphasis on offering new products [51]. One of study results showed that there was a negative relationship between market turbulence and organizational performance [19]. On the other hand, [52] found that market turbulence had a positive moderating effect on quality management infrastructure practice and product innovation performance. Reference [53] found the moderating influence of external environment such as technological turbulence and market turbulence on the relationship between technological innovation capabilities and business performance. Those mean that the increasing market turbulence will affect the relationship between CRM practices and organizational performance [10]. However, another study found that relationship between CRM effectiveness and business performance was not moderated by market turbulence [54].

The market turbulence concept tries to simultaneously evaluate the market dynamism and the market uncertainty [55]. The market dynamism refers to the change that the firms face from a set of clients and competitors. Apart from environmental conditions, market dynamism is emphasized as another important factor that affects firm performance [56]. In a market economy there is always a factor of uncertainty that could cause the "known information" to change substantially. The market uncertainty refers to the difficulty to prepare the organization to cope with the new competitive scenarios. To examine the moderating effect of market turbulence on the relationship between CRM implementation and corporate performance, hypotheses were constructed as follow:

H3. Market turbulence negatively moderates the relationship between CRM implementation and corporate performance. 
The research model showing relationship between all variables which have been discussed above is presented in Figure 1.

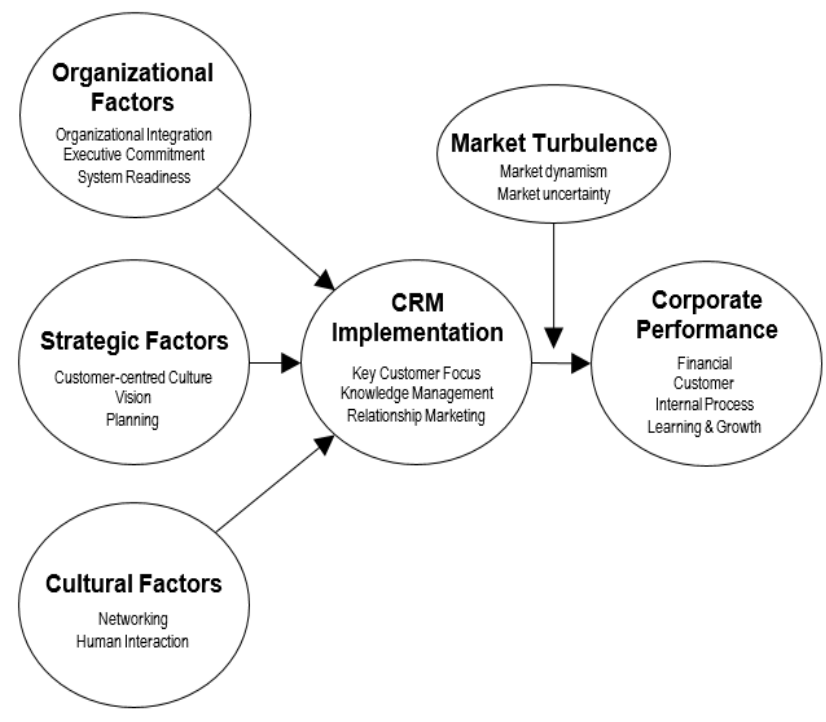

Figure 1 Research Model

\section{METHODS}

This study aims to determine the depiction and the effect of perceived ease of use on interest in using mobile commerce applications. This study used an explanatory survey with the research object of Indonesian ecommerce consumers who previously used e-commerce websites. The sampling technique used quota sampling with a total of 400 samples. The data analysis technique was multiple linear regressions with the SPSS 22.0 for Windows program.

\section{RESULTS AND DISCUSSION}

The results for structural equation model fit indices meet the requirement of satisfactory fitting as shown in Table 1.

Table 1. Goodness of fit indices

\begin{tabular}{|l|l|}
\hline Fit Indices & Value \\
\hline Chi-Square & 95.027 \\
\hline Significanced Probability & .173 \\
\hline RMSEA & .035 \\
\hline GFI & .915 \\
\hline CMIN/DF & 1.145 \\
\hline TLI & .992 \\
\hline CFI & .994 \\
\hline
\end{tabular}

Furthermore, the results shown in Table 2 demonstrates a positive and significant relationship between organizational factors and CRM implementation, strategic factors and CRM implementation, and cultural factors and CRM implementation. This findings support the hypotheses H1. The result also indicates that CRM implementation has a significant and high positive effect on corporate performance. This result shows that the hypotheses $\mathrm{H} 2$ is supported according to regression analyses.

Table 2. Standardized regression weights

\begin{tabular}{|l|l|l|}
\hline & Estimate & P \\
\hline $\begin{array}{l}\text { CRM Implementation } \leftarrow \\
\text { Organizational Factors }\end{array}$ & .286 & .022 \\
\hline $\begin{array}{l}\text { CRM Implementation } \leftarrow \\
\text { Strategic Factors }\end{array}$ & .299 & .034 \\
\hline $\begin{array}{l}\text { CRM Implementation } \leftarrow \\
\text { Cultural Factors }\end{array}$ & .274 & .047 \\
\hline $\begin{array}{l}\text { Corporate Performance } \leftarrow \\
\text { CRM Implementation }\end{array}$ & .936 &.$* * *$ \\
\hline
\end{tabular}

Additionally, interaction test for moderating variable was conducted to investigate the role of market turbulence. The result shows that there is a negative and significant effect of market turbulence on the relationship between CRM implementation and corporate performance. It means that the hypotheses $\mathrm{H} 3$ is supported. The results of the interaction test are shown in Table 3.

Table 3. Interaction test results

\begin{tabular}{|l|l|l|}
\hline & Estimate & P \\
\hline $\begin{array}{l}\text { Corporate Performance } \leftarrow \text { CRM } \\
\text { Implementation }\end{array}$ & .876 &.$* * *$ \\
\hline $\begin{array}{l}\text { Corporate Performance } \leftarrow \text { Market } \\
\text { Turbulence }\end{array}$ & .127 & .007 \\
\hline $\begin{array}{l}\text { Corporate Performance } \leftarrow \\
\text { Moderator }\end{array}$ & .005 &.$* * *$ \\
\hline
\end{tabular}

* Result of statistical test 2019

\section{CONCLUSIONS}

The purpose of this study was to examine the relationship between CRM implementation and corporate performance. The results showed that CRM implementation positively affected corporate performance. This findings support the [10] findings that CRM practices had a significant positive effect on organizational performance. The results also support other previous studies of CRM impact on organizational performance [44-46, 49]. This finding is different from [50] research finding where there was not a direct effect of CRM on firm performance. The relationship between $\mathrm{CRM}$ and firm performance was fully mediated by business strategy, namely differentiation and cost leadership. Reference [57] also found that new product performance mediated the relationship between CRM and company performance. Reference [58] found that the 
indirect effect of CRM on firm performance through innovation was significant. Marketing capability could also mediate the association between CRM technology use and performance [28].

The other finding showed that all indicators of organizational, strategic, and cultural factors were important in implementation of CRM. While [6] found that only organizational integration, vision, and human interaction were important.

The results of this study also showed the significant moderating effect of market turbulence. Its negative moderating effects support previous studies $[10,19,53$, 54]. On the other hand, [52] that market turbulence had a positive moderating effect. The other study even found that the relationship between CRM effectivenss and business performance was not moderated by market turbulence [54].

\section{Limitation and Future Research}

This study has several limitations that can open up avenues fo future research. First, data was collected from one side of courier companies that performed B2B marketing. Although this method is consistent with previous researches, responses from both sides of the relationship are recommended for future research. Second, the data of this study were cross-sectional nature which means that only a snapshot of CRM implementations and corporate performances were obtained. Time series data will explore more understanding of the relationships evolve over time. Future research should examine the performance impact of CRM implementation longitudinally. Third, this study only investigated the direct effect of CRM implementation on corporate performance. Future research could investigate other variables that might mediate the relationship between CRM implementation and corporate performance, such as business strategy [50], new product performance [57], marketing capability [28] and innovation [58]. Reference [50] underscored the need to move beyond a focus on the direct link between CRM and performance in seeking to understand the mechanisms and conditions that influence how and when CRM affects organization success.

\section{ACKNOWLEDGMENTS}

The researcher expressed gratitude to the Postgraduate School of UPI Bandung, especially the Advisor of Program Study of Management. Furthermore, the research respondents who have contributed to the success of this research. This research will not be possible without the support of various parties.

\section{REFERENCES}

[1] R. Davis, "The wizard of OZ in crmland: CRM'S need for business process management," Inf. Syst. Manag., 2002.

[2] D. K. Rigby, F. F. Reichheld, and P. Schefter, "Avoid the four perils of CRM," Harvard Business Review. 2002.

[3] [A. M. Croteau and P. Li, "Critical success factors of CRM technological initiatives," Can. J. Adm. Sci., 2003.

[4] D. L. Goodhue, B. H. Wixom, and H. J. Watson, "Realizing business benefits through CRM: Hitting the right target in the right way," MIS Q. Exec., 2002.

[5] N. Woodcock and M. Starkey, “'I wouldn't start from here': Finding a way in CRM projects," J. Database Mark. Cust. Strateg. Manag., 2001.

[6] H. Darvish, A. R. Kafashzadeh, and H. Ahmadnia, "Studying the Customer Relationship Management: A Case Study at Persian Technology Firm," Econ. Insights Trends Challenges, 2012.

[7] K. Das and J. Parmar, "Customer relationship management (CRM) best practices ans customer loyalty: A study of Indian retail banking sector," Eur. J. Soc. Sci., 2009.

[8] [L. Y. M. Sin, A. C. B. Tse, and F. H. K. Yim, "CRM: Conceptualization and scale development," European Journal of Marketing. 2005.

[9] S. I. Wu and C. L. Lu, "The relationship between CRM, RM, and business performance: A study of the hotel industry in Taiwan,” Int. J. Hosp. Manag., 2012.

[10] S. H. Mohamad, N. A. Othman, J. Jabar, and I. A. Majid, "Customer relationship management practices: The impact on organizational performance in SMEs of food manufacturing industry,” Eur. J. Bus. Manag., 2014.

[11]I. Chaston, "Business-to-business and industrial maketing, new marketing strategies: evolving flexible processes to fit market circumstance," SAGE Publ., 1999.

[12] R. K. Miller and K. D. Washington, "Business-tobusiness marketing 2016-2017," Richard K. Mill. Assoc., 2016.

[13] R. Baxter and A. Woodside, "Deep knowledge of B2B relationships within and across borders," Emerald Gr. Publ. Ltd., 2013.

[14] Gardial, "Customer relationship management (CRM),” Encycl. Heal. Care Manag., 2004. 
[15] Q. Chen and H.-M. Chen, "Exploring the success factors of eCRM strategies in practice," J. Database Mark. Cust. Strateg. Manag., 2004.

[16] R. K. Srivastava, T. A. Shervani, and L. Fahey, "Marketing, business processes, and shareholder value: An organizationally embedded view of marketing activities and the discipline of marketing," J. Mark., 1999.

[17]U. Šebjan, S. Bobek, and P. Tominc, "Organizational Factors Influencing Effective Use of CRM Solutions,” Procedia Technol., 2014.

[18] M. Valsecchi, F. M. Renga, and A. Rangone, "Mobile customer relationship management: An exploratory analysis of Italian applications," Bus. Process Manag. J., 2007.

[19] M. Shabir, S. Ghaffar, Q. A. Nisar, and S. Younas, "Effect of CRM practices on organizational performance under moderation by market turbulence: A study on telecommunication sector of Pakistan.," Comput. Eng. Intell. Syst., 2016.

[20] J. R. Dienhart and M. B. Gregoire, "Job satisfaction, job involvement, job security, and customer focus of quick-service restaurant employees," J. Hosp. Tour. Res., 1993.

[21]B. Manville and N. Foote, "Understanding knowledge management," Long Range Plann., 1996.

[22] B. Karakostas, D. Kardaras, and E. Papathanassiou, "The state of CRM adoption by the financial services in the UK: An empirical investigation," Inf. Manag., 2005.

[23]C. Gronroos, "Defining marketing: A marketoriented approach,” Eur. J. Mark., 1989.

[24] A. Osarenkhoe and A. Z. Bennani, “An exploratory study of implementation of customer relationship projects.,” Bus. Process Manag. J., 2007.

[25] A. M. Zamil, “Customer relationship management: A strategy to sustain the organization's name and products inthe customer's mind," Eur. J. Soc. Sci., 2011.

[26] Y. Chetioui, H. Abbar, and Z. Benabbou, "Organizational factors affecting customer relationship management in service companies: Case of Moroccan banks," Int. J. Innov. Sci. Res. Technol., 2017.

[27] M. Laketa, D. Sanader, L. Laketa, and Z. Misic, "Customer relationship management: concept and importance of banking sector," UMTS J. Econ., 2015.
[28] W. Chang, J. E. Park, and S. Chaiy, "How does CRM technology transform into organizational performance? A mediating role of marketing capability,” J. Bus. Res., 2010.

[29] I. J. Chen and K. Popovich, "Understanding customer relationship management (CRM): People, process and technology," Bus. Process Manag. J., 2003.

[30] D. K. Rigby and D. Ledingham, "CRM done right," Harvard Business Review. 2004.

[31]R. Kotorov, "Customer relationship management: Strategic lessons and future directions," Bus. Process Manag. J., 2003.

[32]E. Blery and M. Michalakopoulos, "Customer relationship management: A case study of a Greek bank,” J. Financ. Serv. Mark., 2006.

[33] M. Fayerman, "New directions for institutional research," Wiley Period., 2002.

[34]F. Buttle, "Customer Relationship Management: Concepts and Tools," Elsevier Butterworth Heinemann, Oxford., 2004.

[35] J. P. Kotter, "Leading Change: Why Transformation Efforts Fail Harvard Business Review,” Harv. Bus. Rev., 1995.

[36] D. Brendler, W.F., \& Loyle, "8 critical factors that make or break CRM," Target Mark., 2001.

[37] K. L. Lau, S. W. Wong, M. M. Ma, and C. Liu, "Next product to offer for bank market," J. Database Manag., 2003.

[38]F. Alduwailah and M. Ali, "The effect of organizational culture on CRM success," in Proceedings of the European, Mediterranean and Middle Eastern Conference on Information Systems, EMCIS 2013, 2013.

[39] M. A. A. Ali and S. Alshawi, “A cultural approach to study customer relationship management (CRM) systems," ResearchGate, 2013.

[40]R. Iriana, F. Buttle, and L. Ang, "Does organisational culture influence CRM's financial outcomes?,” J. Mark. Manag., 2013.

[41] D. Gilbert and J. Tsao, "Exploring Chinese cultural influences and hospitability marketing relationships," Int. J. Contemp. Hosp. Manag., 2000.

[42]P. F. Drucker, "Behind Japan's success-defining rules for managing in a pluralist society," Harv. Bus. Rev., 1981.

[43] S. T. Li, L. Y. Shue, and S. F. Lee, "Enabling customer relationship management in ISP services 
through mining usage patterns," Expert Syst. Appl., 2006.

[44]H. Sayed Soliman, "Customer relationship management and its relationship to the marketing," Int. J. Bus. Soc. Sci., 2011.

[45] A. Mozaheb, S. M. A. Alamolhodaei, and M. F. Ardakani, "Effect of Customer Relationship Management (CRM) on Performance of SmallMedium Sized Enterprises (SMEs) Using Structural Equations Model (SEM)," Int. J. Acad. Res. Accounting, Financ. Manag. Sci., 2015.

[46]M. D. Mohamud, "The effect of customer relationship management and organizational performance in Mogadishu Somalia," Int. J. Sci. Res., 2019.

[47] A. M. Kebede and Z. L. Tegegne, "The effect of customer relationship management on bank performance: In context of commercial banks in Amhara Region, Ethiopia," Cogent Bus. Manag., 2018.

[48] A. Fattah and M. Al-Azzam, "The impact of customer relationship management on hotels performance in Jordan 1,” 2016.

[49] W. Reinartz, M. Krafft, and W. D. Hoyer, "The CRM Process: Its Measurement and Impact on Performance by,” J. Mark. Res., 2004.

[50] O. Schilke and J. Thomas, "Customer relationship management and firm performance: the mediating role of business strategy," Acad. Mark. Sci., 2009.

[51] G. T. M. Hult, R. F. Hurley, and G. A. Knight, "Innovativeness: Its antecedents and impact on business performance,” Ind. Mark. Manag., 2004.
[52] Q. Zhang, X. Feng, and X. Xiang, "The impact of quality management practices on innovation in China: The moderating effects of market turbulence,” Am. J. Ind. Bus. Manag., 2016.

[53]F. B. T. Rahim and Y. Bin Zainuddin, "Moderating effect of environmental turbulence on firm's technological innovation capabilities (TIC) and business performance in the automotive industry in Malaysia: A conceptual framework," in MATEC Web of Conferences, 2016.

[54] M. Abbas and M. Ul Hassan, "Moderating impact of environmental turbulence on business innovation and business performance," Pakistan J. Commer. Soc. Sci., 2017.

[55] M. L. Santos-Vijande and L. I. Álvarez-González, "Innovativeness and organizational innovation in total quality oriented firms: The moderating role of market turbulence," Technovation, 2007.

[56] C. Zehir and D. Balak, "Market dynamism and firm performance relation: The mediating effects of positive environment conditions and firm innovativeness,” EMAJ Emerg. Mark. J., 2018.

[57] H. Ernst, W. D. Hoyer, M. Krafft, and K. Krieger, "Customer relationship management and company performance-the mediating role of new product performance,” J. Acad. Mark. Sci., 2011.

[58] M. Battor and M. Battor, "The impact of customer relationship management capability on innovation and performance advantages: Testing a mediated model,” J. Mark. Manag., 2010.. 